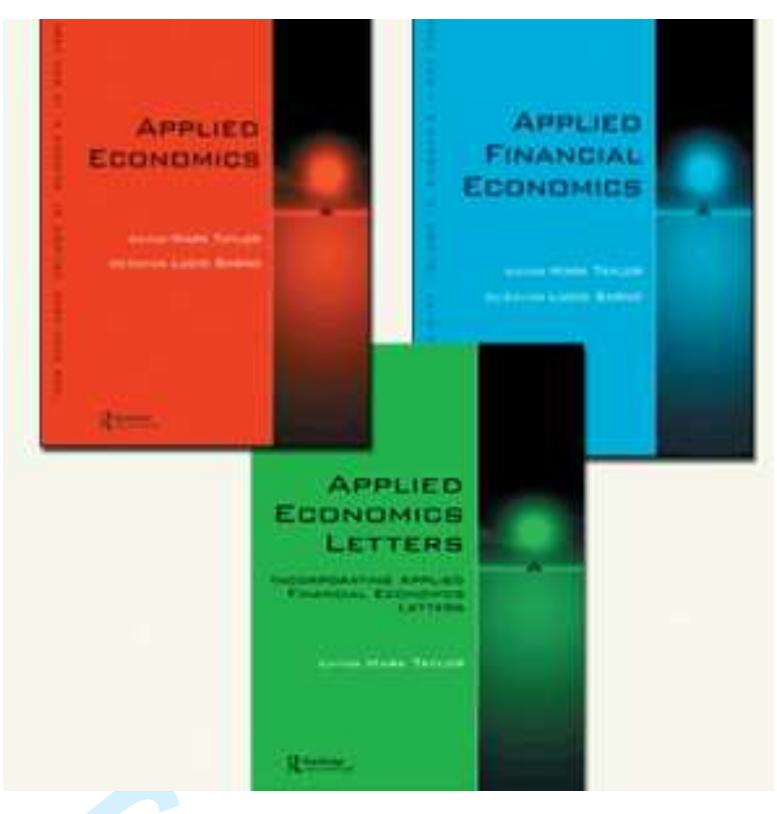

\title{
Do Differences in Institutional and Legal Environments Explain Cross-Country Variations in IPO Underpricing?
}

\begin{tabular}{|r|l|}
\hline Journal: & Applied Economics \\
\hline Manuscript ID: & APE-2010-0048.R1 \\
\hline Journal Selection: & Applied Economics \\
\hline Date Submitted by the \\
Author: & 21-Jun-2011 \\
\hline Complete List of Authors: & $\begin{array}{l}\text { Hopp, Christian; University of Vienna } \\
\text { Dreher, Axel; Heidelberg University, Economics }\end{array}$ \\
\hline JEL Code: & $\begin{array}{l}\text { G15 - International Financial Markets < G1 - General Financial } \\
\text { Subsets < G - Financial Economics, H20 - General < H2 - Taxation, }\end{array}$ \\
\hline Keywords: & IPO underpricing, institutions, legal infrastructure, panel data \\
\hline
\end{tabular}

\section{SCHOLARONE \\ Manuscripts}


JEL-Codes: G15, H2, G1

\author{
C. Hopp ${ }^{\mathrm{a}}$ and A. Dreher
}

\begin{abstract}
June 2011
We empirically analyze the determinants of Initial Public Offering (IPO) underpricing using panel data for 24 countries over the 1988 to 2005 period. Our hypotheses stress the importance of institutional and legal factors in explaining cross-country variations. We find evidence that underpricing is higher in countries with stronger protection of outside investors, suggesting that incumbent managers try to use underpricing as a tool to safeguard their private benefits of control when going public. Moreover, the results show that underpricing is reduced when stronger law enforcement and the availability of accounting information reduce the value of private benefits of control.
\end{abstract}

Acknowledgements: We thank Josef Schuster for support in providing data for various countries studied in this paper, Scott Jobson for careful proof-reading and Wolfgang Drobetz, Li-Anne Woo, Christos Nounis, Jean-Marc Suret, Cecile Carpentier, Wollfgang Aussenegg, Jay Ritter, Suresh Radkrishnan, Silvio Masmara, Matti Keloharju, Tjalling van der Goot, Susana Alvarez-Otero, and Jordi Fabregat for sharing their aggregate IPO data. For helpful comments on an earlier draft we thank seminar participants at the University of Konstanz, the Ohio State University, Rene Stulz, Kewei Hou and Rüdiger Fahlenbrach.

\footnotetext{
a University of Vienna, Department of Economics and Statistics, A-1210 Vienna, Austria, E-Mail: Christian.Hopp@univie.ac.at

b Alfred-Weber-Institut for Economics, University of Heidelberg, 69115 Heidelberg, Germany, E-mail: mail@axel-dreher.de.
} 


\section{Introduction}

One form of raising capital is selling a company's shares on capital markets - i.e., going public. Going public is generally done through an Initial Public Offering (IPO), where shares are sold to investors, usually at a price below those prevailing on the first day of trading (a phenomenon called underpricing: see Ibbotson (1975) for early evidence). As substantial amounts of money are left on the table when personal shares are sold cheaply and the prices for retained shares are diluted, underpricing is costly to firm owners (Ljungqvist, 2006). Nevertheless, as Ritter (2003) shows for a multitude of countries, underpricing is a phenomenon prevailing in almost all equity markets. According to Ljungqvist (2006), pricing discounts vary to a huge extent over time. There are widespread theoretical arguments along with a copious amount of empirical papers explaining the existence of underpricing in equity markets in various countries (see among others Ljungqvist, 2006; Brau and Fawcett, 2006; Allen and Faulhaber, 1989; Welch, 1989; Ritter, 2003). Yet, evidence on the reasons for the changes in underpricing over time, and especially across countries, remains scarce.

Building upon a dataset of 24 countries over the 1988 to 2005 period we analyze whether, and to what extent these differences explain variations in IPO underpricing in our sample across countries and over time. The dataset includes the number of IPOs along with the corresponding aggregated level of underpricing on a yearly basis. The countries comprise nearly all established and developing financial markets, ranging from Western Europe to Asia and the Americas. We follow the research agenda proposed by La Porta et al. (1998) and consider how the protection of investors across countries affects stock markets and ownership patterns around the world. We extend the literature on IPO underpricing and contribute to the growing literature on "law and finance," showing how legal and institutional environments affect equity markets. Our results show that underpricing rises significantly when market returns are generally higher, implying market momentum. When equity markets perform well, 
investors anticipate that companies and investment banks try to time the market when going public and therefore require higher underpricing in return. We find cross-country evidence that illustrates the important control implications of decisions to go public. While previous studies provide either single country evidence (Brennan and Franks, 1997) or survey evidence (Brau and Fawcett, 2006), our results supplement these studies in a multi-country setting, showing that managers try to safeguard the private benefits they possess through control when issuing new shares to outside investors.

Moreover, our results exhibit evidence that stricter law enforcement and a larger availability of accounting information have an adverse effect on underpricing. We find that having more information available and stricter law enforcement reduces the value of the private benefits of control. Accordingly, only a lower level of underpricing can be offered to offset the loss in the absolute value of these private benefits of control when issuing new shares to the public. While investor protection increases underpricing, the findings document that stricter law enforcement and more accounting information actually lead to lower levels of underpricing.

We proceed as follows. The next section elaborates on the factors that might contribute to the cross-country variations in underpricing, and develops our hypotheses. The third section describes the data and method of estimation; in the fourth section we present the results of our analysis, while we discuss extensions in section five. The final section concludes the paper.

\section{Determinants of Cross Country Variations in IPO Underpricing}

Underpricing is linked to the fact that shares being publicly traded for the first time jump in price substantially on the first day of trading. According to Ljungqvist (2006), IPO underpricing can generally be attributed to asymmetric information, institutional reasons, control considerations and behavioral aspects. Ritter (1984) argues that underpricing is related 
to the ex ante uncertainty about the future value of a firm going public. As such, the level of underpricing can be regarded as a compensation for the risk bearing of investors, which seems to have a first order effect on the existence and level of underpricing.

Models of asymmetric information assume that one of the involved parties during the process of taking a firm public is more informed than others, thereby causing the underpricing of shares. Welch (1989) and Allen and Faulhaber (1989) argue that the issuer possesses more information about the true value of the company than potential investors. Underpricing is used to signal firm quality and high-quality firms can make up for the money left on the table initially during a seasoned equity offering in the future.

With respect to the role of institutional factors, Ibbotson (1975) argues that companies going public rely on underpricing to avoid future lawsuits from shareholders due to possibly inaccurate information or too optimistic future outlooks. Hughes and Thakor (1992) point out that intentional underpricing might serve as an insurance against such litigations. Ljungqvist (2006), however, argues that the empirical support for this claim is ambiguous, whereas it might have a second order effect on IPO underpricing. He emphasizes that information asymmetries cause the existence of underpricing while institutional factors affect the extent of underpricing.

\section{Investor protection}

Balancing the trade-off between the new equity received and the control handed over to new outside investors is crucial when going public. According to Zingales (1995) and Dyck and Zingales (2004), the incumbents' intention is to retain control. Directors of IPO firms wish to safeguard their private benefits of control, maintaining control even after shares have been 
sold to the public. ${ }^{1}$ One way to achieve this would be through an increased level of underpricing (Brennan and Franks, 1997). Underpricing ensures a wider demand for new issues and eventually induces a wider dispersion of ownership, thus diluting the monitoring opportunities for outside shareholders (Perotti, 1995; Biais and Perotti, 2002). ${ }^{2}$

Empirical work by Brennan and Franks (1997) illustrates how firms going public can use underpricing to achieve a more dispersed ownership structure. They document that underpricing induces oversubscription and rationing in the process of share allocation, thereby allowing owners to discriminate between aspiring shareholders, which subsequently reduces the block size of new shareholdings.

Accordingly, proceeds are reduced in the presence of discounts offered to new investors. Directors of IPO firms are therefore trading off the value of control against the potential "money left on the table" in an IPO.

Brau and Fawcett (2006) present survey evidence on the reasons for going public and the concerns that cause firms to remain private. Chief Financial Officers are fully aware of underpricing expectations and $41 \%$ of them use underpricing to achieve a widely dispersed ownership structure. The results concerning the firms that stay private indicate that older firms in particular are concerned with losing decision-making power after the IPO. $56 \%$ argue

\footnotetext{
${ }^{1}$ Previous studies elucidate on the gestalt of these private benefits, such as perquisites, value of information, the pleasure of command etc. While the peculiarities can take different forms, private benefits of control share a common characteristic in that [...some value, whatever the source, is not shared among all shareholders in proportion of the shares owned, but is enjoyed exclusively by the party in control.] (Dyck and Zingales, 2004, p. 541).

${ }^{2}$ Empirical evidence suggests that when owners are transferring controlling stakes in an IPO, lower underpricing is observed as there are no private benefits of control that need to be safeguarded, but rather controlling blocks are sold at higher prices.
} 
that decision-making control is the main motive for remaining private. Hence, these concerns induce them not to take their company public, with insiders having strong incentives to keep their firm a private company. Potential benefits from the IPO are outweighed by the risk of losing corporate control.

Across countries, the protection of investors differs widely. In some countries insiders can more easily determine the impact of various actions to the detriment of ordinary investors. While newly founded companies might suffer from weak investor protection due to underinvestment, more established firms might favor lower investor protection and corresponding enforcement of regulations. Without sound investor protection, owners of controlling blocks of shares can dilute the rights of outside minority shareholders after the IPO. Controlling shareholders yearn for weaker legal rules and enforcement in order to safeguard their private benefits of control. They may even lobby for it through political channels (Pagano and Volpin, 2001). When issuing shares in countries with stronger investor protection, the loss of control might become more severe for incumbent managers (Chowdry and Sherman, 1996). New shareholders receive more rights for the same equity piece when investors' rights are more protected. Accordingly, considerations regarding corporate control might differ across countries when issuing shares to the public. In countries with lower investor protection, the loss in the value of private benefits of control for incumbent owners is lower and thus firms are more concentrated after the IPO. Correspondingly, less underpricing is required to maintain the desired level of private benefits of control. On the contrary, new outside owners in countries with stronger protection have more ability to dilute the controlling benefits; therefore an even more dispersed ownership structure might be preferable in order to maintain an equivalent level of private benefits after the IPO. However, this might come at the cost of offering a higher level of underpricing (that is shared among controlling and noncontrolling insiders upon establishment of the IPO). Consequently, greater levels of 
underpricing in countries with stronger investor protection might "buy" a more dispersed ownership structure that reduces monitoring. ${ }^{3}$ Accordingly, we formulate our first hypothesis:

Hypothesis 1: More investor protection causes a higher level of underpricing.

\section{Law enforcement}

In addition to investor protection specified in the legal framework of countries, the enforcement of laws and the availability of accounting information can compensate for weaker rules (La Porta et al., 1998). In this way, functioning and active courts, alongside more transparent accounting information, can safeguard the interests of new outside investors. As pointed out in La Porta et al. (1998) and Pagano and Volpin (2001), regulations are unequally enforced in many countries. While similar regulations might exist, the extent of enforcement differs greatly. Pagano and Volpin (2001) relate these differences to power imbalances between social and economic constituencies. The quality of contractual arrangements is therefore crucially dependent on the quality of legal protection and the ability of legal systems to enforce contracts. In addition to stronger investor protection, stricter law enforcement can limit the risk of outside investors being expropriated by inside managers. Hence, stronger law enforcement might also positively affect the incentives for insiders to use underpricing as a tool to reduce monitoring in the aftermath of the IPO. Consistent with the argument laid out before, we formulate the following hypothesis:

\footnotetext{
${ }^{3}$ Another argument in support of this would be that underpricing may act as an insurance against future lawsuits caused by shareholders' disappointment over post-IPO performance. Litigation may be based on misstated material or omitted facts in the IPO prospectus. Therefore, a higher degree of law enforcement and investor protection should increase the level of underpricing. We thank an anonymous reviewer for raising this point.
} 
Hypothesis 2: Stricter law enforcement causes a higher level of underpricing.

\section{Accounting information}

The availability of information for investors is one of the key determinants in resource allocation. High-quality information plays a crucial role in reducing information asymmetries and mitigating potential agency conflicts (Bushman et al., 2004). Inefficient capital budgeting could stem from costly external financing (driven by information asymmetries between managers and investors) or managers pursuing their own interests instead of maximizing the value of the firm (caused by a lack of efficient corporate governance). Grossman and Stiglitz (1980) conjecture that lower costs of private information should lead to more informative stock prices, with disclosure therefore attenuating information and transaction costs. Hence, more informative stock prices convey more meaningful signals about the quality of managerial decisions, which facilitates the oversight of such decisions and makes corporate governance more effective. ${ }^{4}$ In line with this argumentation, we would expect that greater accounting transparency leads to more firm-specific variation in stock prices, and therefore more informative stock prices which allow for more efficient governance of managerial decisions (Durnev et al., 2004). Consequently, governing managerial actions in the aftermath of the IPO becomes easier for outside shareholders and as a result of this, a more dispersed ownership structure which ensures the attainment of private benefits for controlling shareholders, can only be achieved by offering a higher underpricing to new investors. In contrast to the arguments made above, more accounting information could also work to the detriment of controlling shareholders, even before considering an IPO. Accounting scrutiny might even affect the value of private benefits of control before taking the firm public. If more information is available (for example through quarterly or annual reports), this could benefit

\footnotetext{
${ }^{4}$ Additionally, Core et al. (1999) find evidence that firms with weaker governance structures exhibit more severe agency problems. Less efficient corporate governance structures lead to more excessive executive pay, thereby causing firms to perform worse in terms of future operations and stock market performance.
} 
other stakeholders who have a vested interest in the company, subsequently reducing the level of private benefits of control for incumbent shareholders, even before the firm has issued new shares. More information about the way insiders act in their own interest might be available, thus putting limits on self-interested behavior. Hence, after issuing new shares, incumbent owners might experience lower private benefits of control, and as a consequence, lower levels of underpricing might be required to balance the difference between the value of private benefits of control before and after the IPO ${ }^{5}$ Underpricing could be lower (as the overall level of private benefits of control pre-IPO is lower) in countries with more accounting information available to outside investors. Hence, the effect of institutional environments could well be ambiguous. Accordingly, we formulate the following set of hypotheses.

Hypothesis 3a: Greater corporate transparency and financial disclosure causes a higher level of underpricing.

Hypothesis 3b: Greater corporate transparency and financial disclosure causes a lower level of underpricing.

\section{Data and Method}

Cross country variations in IPO activity and underpricing

\footnotetext{
${ }^{5}$ Moreover, stricter law enforcement and more accounting information (affecting the value of private benefits of control before the IPO, and influencing the rights of new outside shareholders after the IPO) might cause some firms to remain private. When taking a company public, the total valuation of the firm (partly) sold consists of private benefits of control and an income component. While the private benefits by nature are only incurred by the incumbent owner; the observable and verifiable income component would partly belong to the new owners as well. When the potential buyer dilutes the value of cash flow rights it might be more profitable to keep the company private and negotiate over the entire company directly, rather than pursuing an IPO (Zingales, 1995).
} 
Our dataset includes more than 500 country-year observations from 24 countries over the 1988 to 2005 period. Owing to the fact that some of the data are not available for all countries in every year in our panel, the data are unbalanced and the number of observations depends on the choice of explanatory variables. We have aggregated the levels of IPO underpricing over all issues for each country within each year. Our dependent variable is the annual median level of IPO underpricing as a percentage for each country in the dataset. IPO underpricing is calculated as the difference between the offering price of publicly sold shares to investors and the price at which the same shares are subsequently traded at on the stock market. Our IPO data arise from various sources, which are shown in Appendix C.

\section{[Insert table 1 about here]}

Table 1 summarizes the total number of IPOs and the corresponding average level of underpricing over the 1988 to 2005 period. Moreover, we report the maximum and minimum levels of underpricing. As can be seen, IPOs are on average underpriced in almost all countries, in line with Ljungqvist (2006). ${ }^{6}$ However, the reported numbers in our paper might differ slightly, as we report the average level of IPO weighted by the inverse of the corresponding number of IPOs for each year. Underpricing is calculated as the initial first day trading return (Ritter, 2003; Ljungqvist, 2006). Hence, we use the difference between the opening price and the last trading price on the first trading day to arrive at the level of underpricing. If trading was restricted to a maximum fluctuation on the first day of trading, we used the time window indentified in the original article. All data sources are listed and referenced in the appendix. From this it seems that first day returns are subject to large

\footnotetext{
${ }^{6}$ Moreover, the reported numbers are similar to the average numbers provided by Jay Ritter on his IPO website at: http://bear.cba.ufl.edu/ritter/ipodata.htm (Last Accessed May 16th, 2011).
} 
fluctuations over time and across countries. The table also shows that the number of companies going public varies widely across countries.

As can be seen, the United States (with almost 6600 IPOs over the 1988 to 2005 period), India (with some 2700) and Australia (with some 1200) represent the most active countries in the sample. There are also some countries in the sample with a much lower number of IPOs. With respect to the extent of underpricing, the table shows that the weighted average level of underpricing (weighted by the corresponding number of IPOs in the given years) is highest for India (96\%) followed byMalaysia (87\%). Overall, Asian countries rank highest with respect to the overall level of underpricing observed over the period investigated. When looking at the variations in underpricing (the deviations in average levels over the years), table 1 indicates the same trend. Similarly large variations can also be found when comparing maximum and minimum levels of IPO underpricing over time.

\section{Method of estimation}

In the following, we analyze which factors contribute to the observable difference in IPO underpricing across countries and over time.

Our equations take the following form:

$$
\text { underpricing }_{i t}=\alpha+\beta X_{i t}+\eta_{t}+\varepsilon_{i t}
$$

where underpricing $_{i t}$ represents IPO underpricing, $\boldsymbol{X}_{i t}$ is the vector of variables testing for our hypotheses, $\eta_{t}$ are fixed period effects, while $\varepsilon_{i t}$ is the disturbance term. As most of our variables of interest do not vary over time, we cannot estimate fixed effects models. Our models shown below therefore include random country effects. ${ }^{7}$

\footnotetext{
${ }^{7} \mathrm{We}$ also tested for serial correlation in the residuals, which does not seem to be substantial here. Specifically, correlation is 0.3 for the first lag, 0.09 for the second and 0.03 for the third.
} 
The data for this study are drawn from a wide range of sources. Appendix A lists all variables with the exact sources and definitions, while table 2 reports descriptive statistics.

[Insert table 2 about here]

In our basic equation we control for general country characteristics, which are not directly attributable to one of the hypotheses, but rather proxy for the overall state of a country's development. Our basic equation includes a country's average yearly market rate of return (based on log monthly returns), taken from the MSCI Indices. This is done to control for stock market development that could impact upon market timing considerations for issuers - in line with the "hot markets" phenomenon or the Winner's Curse model (Ljungqvist, 2006). Additionally, we included the stock market turnover ratio (taken from Beck et al., 1999). This variable also controls for the consideration of "hot markets," as we would expect countries with more trading activity to induce more underpricing. The model also includes annual GDP growth, along with a variable indicating whether a program with the International Monetary Fund (IMF) has been in place for the corresponding country in a given year for at least 5 months. The GDP growth variable controls for the overall economic development that could potentially influence a country's attractiveness from an investor's perspective. The IMF variable controls for the economic environment - countries under IMF arrangements usually experience economic crises - and external pressure on economic policy. Because we control for economic growth and market returns, we want to rule out external pressure that could have an endogenous impact on these variables. For this reason we also control for countries being under IMF patronage. For countries like India, Singapore and the Philippines, these programs have been in effect throughout the late nineties and therefore might partially affect the market returns and economic growth these countries have experienced. In addition, we also include the number of IPOs in a given year, which enters the regression as a natural logarithm. 
We classify all additional variables in groups that can be allocated to our three hypotheses introduced above. The first step involves adding all variables of one group to the basic equation and following a general-to-specific approach in order to identify the most important determinants of underpricing. Clearly, general-to-specific regressions including all variables would be preferable. However, given the degrees of freedom available and the unbalanced nature of our sample, such procedure is infeasible. We test for the influence of omitted variable bias in further specifications and in our robustness analysis below. Specifically, we include the variables corresponding to the hypotheses formulated above and then remove the variable with the lowest level of significance. With the remaining variables, this procedure is repeated until all coefficients are significant at the $10 \%$ level at least. The second step is to check whether any of the previously deleted variables would render significant when added again. These significant variables are included one by one. The two steps are repeated until a final model is developed. Our next step consists of deriving a final model by combining the variables from the four equations and again following the general-to-specific procedure. ${ }^{8}$

\section{Investor protection}

\footnotetext{
${ }^{8}$ Methodologically, we examine a wide array of potential legal and regulatory influences on IPO underpricing for a large number of countries. Although one might question the approach taken in this paper, we believe that the interrelation between various legal and institutional characteristics calls for an extensive analysis of factors simultaneously influencing the extent of IPO underpricing. While a narrower focus might be more consistent with testing specific theoretical models (e.g., treating one issue separately), in order to gain insights into the driving forces of cross-country differences, one needs to account for a multitude of potential influences at the same time.
} 
In hypothesis 1 we argue that inside owners use underpricing to achieve a wider dispersion of shares when going public in order to safeguard their private benefits of control. In countries with greater investor protection, the loss of control might become more severe for incumbent managers. Accordingly, more underpricing might be required to retain the desired level of private benefits of control.

In order to test this hypothesis we employ a number of measures that are widely used in the recent empirical literature. We use various measures from La Porta et al. (1998) in order to test for the influence of legal environments on the magnitude of IPO underpricing. The antidirectors index measures how strongly the legal system favors minority shareholders over managers and/or dominant shareholders. In order to allow for meaningful inferences, we also included the subcomponents of the antidirectors index. For example, the blocking of shares prior to an annual meeting might make it difficult for minority shareholders to exert their voting rights over majority shareholders. Additionally, we included the number of votes to call an extraordinary shareholders meeting. The higher the required percentage is, the more difficult it becomes for minority shareholders to drive out management. In this light, we also included the oppressed minority measure, which indicates whether minority shareholders have the legal means to take action in the case of fundamental changes within the company (e.g., mergers, asset dispositions etc.). Grossman and Hart (1988) argue that investors might be better protected when dividend rights are linked to voting rights - that is, companies are subject to one-share-one-vote rules. Hence, we also include a dummy indicating whether countries are characterized by such rules. Moreover, we include a variable indicating whether shareholders possess pre-emptive rights when new shares are issued. Having an opportunity to buy new issues of stock would protect shareholders when shares are issued subsequently during seasoned equity offerings, as well as preventing dilution of claims. We also include the other two components of the anti-directors index, which indicate whether the countries under 
investigation allow for mandatory dividends to be paid to shareholders (the percentage of net income paid out as a dividend) and whether voting for the board of directors ensures representation of minority shareholders. Lastly, we include a dummy measuring whether the corresponding country is characterized by civil or common law. Recent research supports the view that countries with civil law systems are associated with greater government intervention in economic activity and weaker protection of private property than common law (La Porta et al., 1998). Accordingly, common law countries have the strongest protection of outside investors whereas (French) civil law countries have the weakest protection.

\section{Law enforcement}

As pointed out in La Porta et al. (1998), laws and especially the quality of enforcement are potentially important factors when analyzing the rights and protection of shareholders. In order to test the underlying argument leading to hypothesis 2, we include variables proxying for the enforcement of laws in the countries under investigation.

Specifically, we employ the International Country Risk Guide (ICRG) index for the rule of law. This variable reflects the government's administrative capacity to enforce the law. Moreover, it measures the potential for rent seeking due to weaker systems and insecure or under-secured property rights. In addition, we supplement our analysis with a measure of bureaucratic quality. High scores on the ICRG bureaucratic quality variable indicate autonomy from political pressure, strength and expertise to govern without drastic changes in policy or interruptions in government services when there is a change in government, and established mechanisms for recruiting and training. We also include a measure of corruption to capture potential influences of "settlements outside of the law." The index of perceived corruption is also provided by the ICRG (2004). This indicator is based on the analysis of a worldwide network of experts. The index ranges from 0 - representing highest corruption - to 
12 (no corruption). From La Porta et al. (1998) we take two measures of contract repudiation and threat of expropriation to proxy for the enforcement of laws. For both measures, higher scores indicate a better enforcement of laws in the respective countries. Lastly, we include a variable measuring the efficiency of the judicial system, taken from La Porta et al. (1998) (respectively Business International Corporation). Higher values indicate a higher level of efficiency and integrity in the legal system.

\section{Accounting transparency}

Turning to hypotheses 3a and 3b, we take several measures from Bushman et al. (2004) in order to proxy for financial and governance disclosure: A measure indicating the inclusion of 90 accounting items in the balance sheet, the disclosure requirements regarding $R \& D$ investments, ${ }^{9}$ a measure referring to the governance and compensation structure of the firm, ${ }^{10}$ an index regarding consolidation and discretionary reserve accounting, and a measure of corporate transparency in terms of timeliness and frequency of reports. Higher values in all indices indicate more disclosure/transparency. These measures supplement the disclosure requirements index provided by La Porta et al. (2006). ${ }^{11}$

\section{Results}

For each hypothesis, table 3 reports two sets of regressions. The first includes the full number of variables we employ to test the respective hypothesis, the second contains the variables selected by the general-to-specific exercise. However, while table 3 reports the results for the base model and the individual hypotheses for transparency reasons, we largely confine our

\footnotetext{
${ }^{9}$ Specifically: capital expenditure, subsidiaries, segment-product, segment-geographic, and accounting policy.

${ }^{10}$ Major shareholders, management information, list of board members and their affiliations, remuneration of directors and officers, and shares owned by directors and employees.

${ }^{11}$ The index incorporates information on the existence of prospectus requirements for issuing firms, whether compensation of directors and shareholder composition and inside ownership has to be disclosed in the prospectus, and whether information regarding contracts and transactions outside the ordinary course of business has to be disclosed.
} 
discussion to the final model. Table 3 presents the variables selected by the individual general-to-specific regressions (denoted as model 8) and the final model (denoted as model 9). Due to the unbalanced nature of our data, the number of observations is reduced to 322 , from 23 countries. Regarding the variables included in the base model, underpricing rises with higher market returns at the $5 \%$ level of significance. The results suggest that when equity markets perform well, investors anticipate that companies and investment banks try to time the market when going public and require higher underpricing in return. Moreover, the results for most models suggest that countries under an IMF program are characterized by higher underpricing; the coefficient is, however, marginally insignificant in the final model. The coefficient for GDP growth is not significant at conventional levels when we control for other factors in the final model, and the same holds for stock market turnover. However, the coefficient for the number of IPOs is positive and significant (at the 5\% level) in the final model. This suggests some evidence for trading activity impacting the overall level of underpricing in the countries examined. It is quite possible that more active markets affect the prices observed after the issuance positively, thus underpricing increases.

[Insert table 3 about here]

With respect to hypothesis 1 , table 3 reveals mixed evidence concerning investor protection and underpricing. While the coefficient associated with the oppressed minority dummy is negative (and significant at the $1 \%$ level), the variables indicating proxy voting by mail, preemptive rights of new issues, and cumulative voting laws are positive and significant (at the $10 \%$ level at least). Moreover, in civil law societies underpricing is significantly lower, with a negative and significant coefficient (at the $1 \%$ level). The remaining variables are not significant at conventional levels. Overall we can see that not all measures employed here 
indicate that more investor protection is detrimental to incumbent managers. Generally, there is some evidence that voting procedures increase the levels of underpricing observed.

In hypothesis 2 we argue that stricter law enforcement should be associated with a higher level of underpricing, as incumbent owners have to offer a higher discount to outside investors to achieve wider ownership dispersion. Columns 4 and 5 in table 3 present the results for the initial model, while columns 8 and 9 present the full and corresponding final model. The results from the full model indicate that in countries where there is a lower risk of repudiation, and laws are correspondingly better protected, there is less underpricing, at the $1 \%$ level. While none of the remaining coefficients are significant at conventional levels in the final model, overall the results present evidence that better law enforcement reduces the level of underpricing.

Finally, hypothesis $3 \mathrm{a}$ argues that greater corporate transparency and financial disclosure should cause a higher level of underpricing, while hypothesis $3 \mathrm{~b}$ predicts that more information and disclosure should reduce the private benefit of incumbents even before a firm goes public. Columns 6 and 7 report the impact of financial disclosure on underpricing in the initial model, while columns 8 and 9 present the full and final model. The results indicate that the accounting index (measuring the inclusion of 90 accounting items in company reports) and corporate transparency are significant (at the $1 \%$ level) and negative. This indicates that when more information about the issuing firm is available, less underpricing is observed. For the governance disclosure variable and $R \& D$ disclosure, we find positive and significant coefficients (at the $1 \%$ level). These results lend support to hypothesis $3 \mathrm{a}$, implying that more information requires a larger level of underpricing when going public. Disclosure requirements and consolidation disclosure are not significant at conventional levels. The results therefore provide only mixed support for either of the two hypotheses. In the next 
section we further test for the robustness of our results before drawing final conclusions with respect to our hypotheses.

\section{Tests for Robustness}

We examine the robustness of our model with variants of the extreme bounds analysis (EBA), a standard procedure in the recent empirical literature. ${ }^{12}$ The approach is described in detail in Appendix B. Almost 2000 specifications with different combinations of control variables are analyzed; following Sala-i-Martin (1997), we consider the impact of our explanatory variables on IPO underpricing to be robust if the fraction of the cumulative distribution function lying on one side of zero $(\mathrm{CDF}(0))$ exceeds $0.90 .{ }^{13} \mathrm{We}$ include all variables in the EBA that have been included in the general-to-specific exercise above.

We present three sets of results. The first set includes our baseline variables in the model and adds all additional variables in combinations of up to three to the regressions. In the second set, the variables included in the final model of column 9 in table 3 are always included in the regressions, while the remaining variables are again added in combinations of up to three. Finally, we report the results for the additional variables when included in the full model one at a time, and again including all other variables in combinations of up to three.

\footnotetext{
${ }^{12}$ See, e.g., Sala-i-Martin (1997), Fernández, Ley and Steel (2001), Sturm et al. (2005), Sturm and de Haan (2005), Gassebner et al. (2006), and Gassebner and Luechinger (2011).

${ }^{13}$ Sala-i-Martin (1997) proposes using the (integrated) likelihood to construct a weighted $\operatorname{CDF}(0)$. However, the differing number of observations in the regressions due to missing observations for some of the variables poses a problem. Sturm and de Haan (2001) show that, as a result, this goodness of fit measure may not be a good indicator of the probability that a model is the true model and the weights constructed in this way are not equivariant for linear transformations in the dependent variable. Hence, changing scales will result in rather different outcomes and conclusions. We therefore restrict our attention to the unweighted version. Furthermore, for technical reasons - in particular our unbalanced panel setup - we are unable to use the extension of this approach called Bayesian Averaging of Classical Estimates (BACE), as introduced by Sala-i-Martin et al.
} (2004). 


\section{[Insert table 4 about here]}

Tables 4 and 5 show the results. As can be seen from the upper part of table 4 , the base model performs quite well, with the $\operatorname{CDF}(0)$ of four variables being above 0.9 . The stock market turnover lies below the critical value of 0.9. Again, when included in the full model specification presented in the lower part of the table, the stock market turnover is not robustly significant. Three of the four remaining variables of the base model are however robust determinants of underpricing, with economic growth being the exception.

Turning to the robustness of the additional variables in the final model, we obtain mixed results. While all variables testing for hypothesis 3 are robust determinants of underpricing, we find only weak evidence regarding hypothesis 1 and 2 .

Generally, better accounting standards and more transparency reduce underpricing, while the inclusion of certain items ( $R \& D$, consolidation and governance) increase underpricing. However, the $\operatorname{CDF}(0)$ shows that the risk of repudiation, as well as the cumulative and proxy voting dummies are slightly below the critical value of 0.90 , while the pre-emptive rights variable is well below it. Finally, table 5 shows that most of the additional variables are indeed not robust determinants of IPO underpricing. Hence, we conclude that there is no robust evidence from any of the sub-components of the anti-directors index and the condensed measures (as employed in various research articles) which explains variations in underpricing (as documented in table 5). Accordingly, when making inferences, the various governance measures collectively appear to carry information on underpricing, rather than the various aspects in isolation. 


\section{Conclusion}

In this paper we analyze the institutional and legal determinants of IPO underpricing across countries and over time. In our basic analysis we test for general country determinants of IPO underpricing. Overall, we find evidence that legal and institutional factors influence variations in underpricing. We attribute these effects mainly to variations in accounting transparency and to discrepancies in legal and institutional environments and the associated levels of enforcement. Transparency influences the dissemination and interpretation of information generated, while legal and institutional environments affect the effectiveness of firm level corporate governance and the incentive for incumbent managers to achieve a reduced level of monitoring. While we do not consider our analysis to be exhaustive, we believe that our results present an early step in analyzing how regulatory, legal and institutional environments shape financial markets and affect the perceived risk of investing.

For future research, it might be rewarding to further investigate which additional factors impact cross-country variations in IPO underpricing. Ljungqvist (2006) points out that firms going public might signal firm quality via increased initial underpricing, subsequently recouping the money initially left on the table when coming back to raise money in successive offerings. Given the lack of data, we did not pursue an analysis of seasoned equity offerings in this paper. However, it could well be that the pricing of seasoned equity offerings might have an impact on the level of underpricing observed. Guiso et al. (2006) analyze the role of culture as a potential determinant of economic outcomes. It might be interesting to test how systematic differences in people's preferences and beliefs interact with the legal and institutional infrastructure of countries. This might enable us to enrich our understanding of economic phenomena by analyzing cultural and institutional characteristics of investment environments simultaneously. 
Additionally, Beck et al. (2005) allude to the important obstacles firms face in obtaining external capital. The more difficult it is to raise external equity, the more likely it will be that firms need to undertake dealings in primary capital markets to raise capital through initial public or seasoned equity offerings. Thus, the large number of less developed firms pending for equity could influence the magnitude of underpricing. Consequently, the institutional framework is also likely to affect the efficiency of the capital-raising process. The services offered by financial intermediaries and the structure of financial systems can impact the internal conflicts the financial institutions are subject to. Moreover, firms with heavier reliance on primary equity capital markets for funding purposes shift risk to equity investors. As such, we would expect underpricing to be higher in less developed financial systems.

Moreover, Jagannathan and Sherman (2006) point out the importance of the pricing mechanisms used in order to explain differences in IPO underpricing across countries. They analyze the use of different IPO pricing mechanisms in various countries and find that among the countries that formerly used IPO auctions, virtually all have abandoned the method. They argue that uniform and discriminatory auctions suffer from large fluctuations in the number of auction participants. Moreover, the free rider problem and the winner's curse make price discovery more difficult. As a consequence, they argue that this might contribute to inaccurate pricing. Accordingly, it might be worthwhile to further expand our analysis by looking into the determinants of pricing mechanisms that may well be endogenous to institutional environments, and how they affect the extent of underpricing observed.

\footnotetext{
We strongly believe that more research into the influences of legal and regulatory frameworks on corporate financing decisions will enhance our understanding of the IPO process and the managerial implications that accompany this. Expanding our approach by using more finite
} 
legal and economic variables, as well as controlling for firm-level information would present an interesting avenue for future research. 


\section{References}

Ahmad-Zaluki, N. A., Campbell, K. and Goodacre, A. (2007) The long run share price performance of Malaysian Initial Public Offerings (IPOs), Journal of Business Finance \& Accounting, 34, 78-110.

Alavi, A., Pham, K. P.and Pham, T. M. (2008) Pre-IPO ownership structure and its impact on the IPO process, Journal of Banking and Finance, 32, 2361-2375.

Allen, F. and G. Faulhaber (1989) Signaling by underpricing in the IPO market, Journal of Financial Economics, 23, 303-324.

Alvarez, S. and Fernandez, A., I. (2003) La explicacion de la infravaloracion de las salidas a bolsa, Revista de Economia Aplicada, 11, 49-64.

Aussenegg, W. (1997) Die Performance österreichischer Initial Public Offerings, Finanzmarkt und Portfolio Management, 11, 413-431.

Aussenegg, W. (2006) Underpricing and the aftermarket performance of Initial Public Offerings - The case of Austria, in: Initial Public Offerings: an international perspective, (Ed) G. N. Gregoriou Elsevier, Quantitative Finance Series, Amsterdam, pp. 187-213.

Beck, T., Demirgüç-Kunt, A. and Levine, R. E. (1999) A new database on financial development and structure, World Bank Policy Research Working Paper No. 2146.

Beck, T., Demirgüç-Kunt, A. and Levine, R. E. (2005) Law and firms' access to finance, American Law and Economics Review, 7, 211-252.

Biais, B. and E. Perotti (2002) Machiavellian Privatization, American Economic Review, 92, 240-258.

Brau, J. and Fawcett, S. (2006) Initial Public Offerings: an analysis of theory and practice, Journal of Finance, 61, 399-436.

Brennan, M. and Franks, J. (1997) Underpricing, ownership and control in initial public offerings of equity securities in the UK, Journal of Financial Economics, $45,391-413$.

Bushman, R., Piotroski, J. and Smith, A. (2004) What determines Corporate Transparency?, Journal of Accounting Research, 42, 207-252.

Chowdry, B. and Sherman, A. (1996) International differences in oversubscription and underpricing of IPOs, Journal of Corporate Finance, 2, 359-381.

Core, J., Holthausen, R. and Larcker, D. (1999) Corporate Governance, chief executive officer compensation, and firm performance, Journal of Financial Economics, 51, 371-406.

Derrien, F. and Womack, K. (2003) Auctions vs. bookbuilding and the control of underpricing in Hot IPO markets, Review of Financial Studies, 16, 31-61. 
Dreher, A. (2006) IMF and economic growth: the effects of programs, loans, and compliance with conditionality, World Development, 34, 769-788.

Drobetz, W., Kammermann, M. and Wälchli, U. (2005) Long-run performance of Initial Public Offerings: the evidence for Switzerland, Schmalenbach Business Review, 59, 253-275.

Durnev, A., Morck, R. and Yeung, B. (2004) Value enhancing capital budgeting and firmspecific stock return variation, Journal of Finance, 59, 65-105.

Dyck, A. and Zingales, L. (2004) Private benefits of control: an international comparison, Journal of Finance, 59, 537-600.

Fernández, C., Ley, E. and Steel, M. F. J. (2001) Model uncertainty in cross-country growth regressions, Journal of Applied Econometrics, 16, 563-576.

Gassebner, M., Lamla, M. and Sturm, J.-E. (2006) Economic, political and demographic determinants of pollution reassessed: a sensitivity analysis, CESifo Working Paper No. 1699.

Gassebner, M. and Luechinger, S. (2011) Lock, stock and barrel: a comprehensive assessment of the determinants of terror, Unpublished Paper, University of Lucerne and ETH Zurich, mimeo.

Grossman, S. and Stiglitz, J. (1980) On the impossibility of informationally efficient markets, American Economic Review, 70, 393-408.

Grossman, S. and Hart, O. (1988) One share/one vote and the market for corporate control, Journal of Financial Economics, 20, 175-202.

Guiso, L., Sapienza, P. and Zingales, L. (2006) Does culture affect economic outcomes?, Journal of Economic Perspectives, 20, 23-48.

Hughes, P. and A. Thakor (1992) Litigation risk, intermediation, and the underpricing of initial public offerings, Review of Financial Studies, 5, 709-742.

Ibbotson, R. G. (1975) Price performance of common stock new issues, Journal of Financial Economics, 2, 235-272.

International Country Risk Guide (2004) The PRS Group, New York.

Jagannathan, R. and Sherman, A. (2006) Why do IPO auctions fail?, Working Paper, University of Notre-Dame.

Jakobson, J. and Sorenson, J. (2002) Decomposing and testing long-run returns with an application to initial public offerings in Denmark, Working Paper, Copenhagen Business School.

Kaneko, T. and Pettway, R. (2003) Auctions versus Book-building underwriting of Japanese IPOs: OTC, Mothers, and NASDAQ-Japan Issues, Pacific-Basin Finance Journal, 11, 439-462. 
La Porta, R., Lopez-de-Silanes, F. Shleifer, A. and Vishny, R. (1998) Law and Finance, Journal of Political Economy, 106, 1113-1156.

La Porta, R., Lopez-de-Silanes, F. and Shleifer, A. (2006) What works in securities laws?, The Journal of Finance, 61, 1-32.

Leamer, E. E. (1983) Let's take the con out of econometrics, American Economic Review, 73, 31-43.

Levine, R. E. and Renelt, D. (1992) A sensitivity analysis of cross-country growth regressions, American Economic Review, 82, 942-963.

Ljungqvist, A. (2006) IPO Underpricing, in Handbook of Empirical Corporate Finance, (Ed) B. Espen Eckbo, North-Holland, Amsterdam,375-418.

Marisetty, V. and Subrahmanyam, M. (2008) Group affiliations and the performance of Initial Public Offerings in the Indian Stock market, Working Paper, Stern School of Business, New York.

Nounis, C. (2005) The Greek IPO Initial Returns and the Price Cap Constraints: Evidence from the Athens Stock Exchange (1994-2003), Working Paper, National and Kapodistrian University of Athens.

Pagano, M. and Volpin, P. (2001) The political economy of finance, Oxford Review of Economic Policy, 17, 502-519.

Perotti, E. C. (1995) Credible privatization, American Economic Review, 85, 847-859.

Ritter, J. (1984) The "Hot Issue" Market of 1980, Journal of Business, 57, 215-240.

Ritter, J. R. (2003) Investment Banking and Securities Issuance, in Handbook of the Economics of Finance, (Ed) George M. Constantinides, Milton Harris and René Stulz, NorthHolland, Amsterdam, 255-306.

Ritter, J., Packer, F. and Hamao, Y. (2000) Institutional affiliation and the role of venture capital: evidence from Initial Public Offerings in Japan, Pacific-Basin Finance Journal, 8, $529-558$.

Saettem, F., Emilsen, H. and Pedersen, K., (1997) Børsintroduksjoner, BETA - Tidsskrift for bedriftsøkonomi, Årg. 11, 1-13.

Sala-i-Martin, X. (1997) I just ran two millions regressions. American Economic Review 87: $178-183$.

Sala-i-Martin, X., Doppelhofer, G. and Miller, R.I. (2004). Determinants of long-term growth: a Bayesian Averaging of Classical Estimates (BACE) approach, American Economic Review, $94,813-835$.

Sturm, J.-E. and de Haan, J. (2001) How robust is Sala-i-Martin's robustness analysis, Unpublished Paper, mimeo, University of Groningen. 
Sturm, J.-E. and de Haan, J. (2005) Determinants of long-term growth: new results applying robust estimation and extreme bounds analysis, Empirical Economics, 30, 597-617.

Sturm, J.-E., Berger, H. and de Haan, J. (2005) Which variables explain decisions on IMF credit? An extreme bounds analysis, Economics \& Politics, 17, 177-213.

Sullivan, M. and Unite, A. (2001) The influence of group affiliation and the underwriting process on emerging market IPOs: The case of the Philippines, Pacific-Basin Finance Journal, 9, 487-512.

Temple, J. (2000) Growth regressions and what the textbooks don't tell you, Bulletin of Economic Research, 52, 181-205.

Welch, I (1989) Seasoned Offerings, Imitation Costs, and the Underpricing of Initial Public Offerings, Journal of Finance, 44, 421-449.

World Bank (2006) World Development Indicators, CD-Rom, Washington, DC.

Zingales, L. (1995) Insider ownership and the decision to go public, Review of Economic Studies, 62, 425-448. 
Table 1: Cross Country Variation of IPOs and IPO Underpricing

\begin{tabular}{|c|c|c|c|c|c|c|}
\hline Country & $\begin{array}{l}\text { Number of } \\
\text { IPOs }\end{array}$ & \begin{tabular}{|l|} 
Weighted \\
Average \\
Underpricing \\
\end{tabular} & $\mid \begin{array}{l}\text { Max. } \\
\text { Underpricing }\end{array}$ & $\mid \begin{array}{l}\text { Min. } \\
\text { Underpricing }\end{array}$ & $\begin{array}{l}\text { Variation in } \\
\text { IPO activity }\end{array}$ & \begin{tabular}{|l} 
Variation in \\
Underpricing
\end{tabular} \\
\hline Australia & 1241 & $24.49 \%$ & $105.42 \%$ & $5.74 \%$ & 56.04 & $25.86 \%$ \\
\hline Austria & 72 & $7.14 \%$ & $24.54 \%$ & $-3.22 \%$ & 3.43 & $7.52 \%$ \\
\hline Belgium & 46 & $9.86 \%$ & $12.45 \%$ & $0.77 \%$ & 4.46 & $5.00 \%$ \\
\hline Canada & 684 & $34.19 \%$ & $59.52 \%$ & $15.95 \%$ & 28.84 & $13.44 \%$ \\
\hline Denmark & 42 & $9.63 \%$ & $22.25 \%$ & $-2.74 \%$ & 1.81 & $7.83 \%$ \\
\hline Finland & 124 & $10.92 \%$ & $35.83 \%$ & $0.77 \%$ & 11.36 & $10.25 \%$ \\
\hline France & 462 & $12.18 \%$ & $19.03 \%$ & $1.87 \%$ & 27.20 & $5.68 \%$ \\
\hline Germany & 513 & $37.78 \%$ & $61.57 \%$ & $-3.50 \%$ & 43.44 & $18.86 \%$ \\
\hline Greece & 341 & $37.42 \%$ & $102.80 \%$ & $-11.30 \%$ & 14.81 & $31.01 \%$ \\
\hline $\begin{array}{l}\text { Hong Kong, } \\
\text { China }\end{array}$ & 517 & $13.12 \%$ & $37.80 \%$ & $-1.48 \%$ & 15.48 & $11.97 \%$ \\
\hline India & 2713 & $96.74 \%$ & $534.82 \%$ & $26.68 \%$ & 249.62 & $140.92 \%$ \\
\hline Italy & 197 & $12.5 \%$ & $71.93 \%$ & $-9.66 \%$ & 10.18 & $20.23 \%$ \\
\hline Japan & 1419 & $26.43 \%$ & $136.63 \%$ & $5.31 \%$ & 37.54 & $32.22 \%$ \\
\hline Malaysia & 507 & $87.12 \%$ & $195.62 \%$ & $-10.70 \%$ & 21.87 & $56.36 \%$ \\
\hline Netherlands & 88 & $14.47 \%$ & $35.12 \%$ & $-4.32 \%$ & 5.72 & $10.54 \%$ \\
\hline New Zealand & 65 & $6.21 \%$ & $26.89 \%$ & -24.00 & 3.83 & $11.92 \%$ \\
\hline Norway & 106 & $10.12 \%$ & $87.35 \%$ & $-7.42 \%$ & 4.99 & $22.96 \%$ \\
\hline Philippines & 109 & $20.27 \%$ & $77.42 \%$ & $-1.69 \%$ & 6.16 & $24.18 \%$ \\
\hline Singapore & 308 & $22.43 \%$ & $55.71 \%$ & $-2.22 \%$ & 19.14 & $18.87 \%$ \\
\hline Spain & 123 & $12.37 \%$ & $28.87 \%$ & $-6.37 \%$ & 7.45 & $9.74 \%$ \\
\hline Sweden & 183 & $17.43 \%$ & $60.60 \%$ & $-0.30 \%$ & 10.46 & $15.84 \%$ \\
\hline Switzerland & 57 & $16.69 \%$ & $42.69 \%$ & $-2.31 \%$ & 4.16 & $12.32 \%$ \\
\hline $\begin{array}{l}\text { United } \\
\text { Kingdom }\end{array}$ & 838 & $13.92 \%$ & $38.32 \%$ & $3.67 \%$ & 42.65 & $8.43 \%$ \\
\hline United States & 6554 & $21.73 \%$ & $72.98 \%$ & $8.48 \%$ & 226.27 & $16.17 \%$ \\
\hline
\end{tabular}

Table 1 reports the cross-country variations in IPO underpricing along with the overall number of IPOs during the period of investigation. Column 2 presents the total number of IPOs included in the dataset. Column 3 presents the weighted average level of underpricing. The yearly percentage returns are weighted by the corresponding number of IPOs in the given year to arrive at the number shown. In addition, columns 4 and 5 show the maximum and minimum yearly returns (based on the aggregated average levels). Columns 6 and 7 show the standard deviation of the yearly number of IPOs and the corresponding variation in returns per country, respectively. 
Table 2: Descriptive Statistics

\begin{tabular}{|l|}
\hline Variable \\
\hline Underpricing \\
Return \\
Economic growth (t-1) \\
IMF program, dummy (t-1) \\
Number of IPOs (log) \\
Relative market efficiency \\
Civil law, dummy \\
One share-one vote, dummy \\
Proxy Voting by Mail, dummy \\
Blocking of shares, dummy \\
Cumulative Voting, dummy \\
Oppressed minority, dummy \\
Preemptive Rights of new Issues \\
Votes to call ext. meeting \\
New antidirectors index \\
Mandatory Dividends, dummy \\
Rule of Law \\
Bureaucratic Quality \\
Corruption \\
Risk of Repudiation \\
Risk of Expropriation \\
Effective Judiciary \\
Accounting Standards \\
Corporate transparency \\
Governance Disclosure \\
R\&D Disclosure \\
Disclosure Requirements, Index \\
Consolidation Disclosure \\
\hline
\end{tabular}

\begin{tabular}{|r|}
\hline \multicolumn{1}{|r|}{ Mean } \\
\hline 0.30 \\
0.07 \\
3.70 \\
0.04 \\
2.55 \\
0.01 \\
0.64 \\
0.18 \\
0.25 \\
0.64 \\
0.25 \\
0.46 \\
0.57 \\
0.09 \\
3.04 \\
0.01 \\
5.16 \\
10 \\
8.69 \\
8.63 \\
9.04 \\
8.32 \\
72.27 \\
71.02 \\
80.85 \\
87.87 \\
0.67 \\
67.58 \\
\hline
\end{tabular}

Minimum Maximum

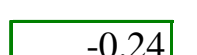


Table 3: Determinants of IPO underpricing, general-to-specific, GLS, 1988-2005

\begin{tabular}{|c|c|c|c|c|c|c|c|c|c|}
\hline \multirow{3}{*}{ Market Return } & \multirow{2}{*}{$\begin{array}{l}(1) \\
\text { Base } \\
0226^{*}\end{array}$} & \multirow{2}{*}{\multicolumn{2}{|c|}{$\begin{array}{l}\text { (2) (3) } \\
\text { Hypothesis } 1\end{array}$}} & (4) & (5) & (6) & (7) & (8) & (9) \\
\hline & & & & \multicolumn{2}{|c|}{ Hypothesis 2} & \multicolumn{2}{|c|}{ Hypothesis 3} & \multicolumn{2}{|c|}{ Full model } \\
\hline & $\begin{array}{l}0.226^{*} \\
(1.85)\end{array}$ & $\begin{array}{l}0.185 \\
(1.40)\end{array}$ & $\begin{array}{l}0.203^{*} \\
(1.70)\end{array}$ & $\begin{array}{l}0.299 * * \\
(2.37)\end{array}$ & $\begin{array}{l}0.225^{*} \\
(1.89)\end{array}$ & $\begin{array}{l}0.301^{* *} \\
(2.54)\end{array}$ & $\begin{array}{l}0.305^{* *} \\
(2.57)\end{array}$ & $\begin{array}{l}0.243^{* *} \\
(2.08)\end{array}$ & $\begin{array}{l}0.233^{* *} \\
(2.00)\end{array}$ \\
\hline Economic growth & $\begin{array}{l}0.029 * * * \\
(2.90)\end{array}$ & $\begin{array}{r}0.009 \\
(0.75)\end{array}$ & $\begin{array}{l}0.011 \\
(0.95)\end{array}$ & $\begin{array}{l}0.005 \\
(0.41)\end{array}$ & $\begin{array}{l}0.008 \\
(0.69)\end{array}$ & $\begin{array}{l}0.013 \\
(1.16)\end{array}$ & $\begin{array}{c}0.012 \\
(1.09)\end{array}$ & $\begin{array}{l}0.002 \\
(0.21)\end{array}$ & $\begin{array}{l}0.003 \\
(0.30)\end{array}$ \\
\hline IMF program, dummy & $\begin{array}{l}0.680 * * * \\
(5.23)\end{array}$ & $\begin{array}{l}0.512 * * * \\
(3.12)\end{array}$ & $\begin{array}{l}0.404 * * * \\
(3.03)\end{array}$ & $\begin{array}{l}0.409 * * \\
(2.52)\end{array}$ & $\begin{array}{l}0.307 * * \\
(2.24)\end{array}$ & $\begin{array}{l}0.374 * * * \\
(2.68)\end{array}$ & $\begin{array}{l}0.389 * * * \\
(2.84)\end{array}$ & $\begin{array}{r}0.153 \\
(1.11)\end{array}$ & $\begin{array}{l}0.190 \\
(1.41)\end{array}$ \\
\hline Number of IPOs (log) & $\begin{array}{l}0.073 * * * \\
(4.87)\end{array}$ & $\begin{array}{l}0.050 * * \\
(2.41)\end{array}$ & $\begin{array}{l}0.044 * * \\
(2.45)\end{array}$ & $\begin{array}{r}0.020 \\
(0.86)\end{array}$ & $\begin{array}{l}0.027 * \\
(1.69)\end{array}$ & $\begin{array}{l}0.053 * * * \\
(3.04)\end{array}$ & $\begin{array}{l}0.054 * * * \\
(3.13)\end{array}$ & $\begin{array}{l}0.034 * \\
(1.80)\end{array}$ & $\begin{array}{l}0.042 * * \\
(2.37)\end{array}$ \\
\hline Stock Market Turnover & $\begin{array}{c}-2.449 \\
(0.93)\end{array}$ & $\begin{array}{r}-2.728 \\
(0.94)\end{array}$ & $\begin{array}{c}-4.214 \\
(1.64)\end{array}$ & $\begin{array}{l}0.794 \\
(0.17)\end{array}$ & $\begin{array}{l}-0.388 \\
(0.15)\end{array}$ & $\begin{array}{l}-2.791 \\
(1.02)\end{array}$ & $\begin{array}{l}-2.600 \\
(0.95)\end{array}$ & $\begin{array}{l}-2.051 \\
(0.70)\end{array}$ & $\begin{array}{l}-1.266 \\
(0.46)\end{array}$ \\
\hline Civil law, dummy & & $\begin{array}{l}-0.516^{* * * *} \\
(3.69)\end{array}$ & $\begin{array}{l}-0.528 * * * \\
(5.25)\end{array}$ & & & & & $\begin{array}{l}-0.300^{*} \\
(1.82)\end{array}$ & $\begin{array}{c}-0.407 * * * \\
(4.02)\end{array}$ \\
\hline One share-one vote, dummy & & $\begin{array}{l}-0.021 \\
(0.21)\end{array}$ & & & & & & & \\
\hline Proxy Voting by Mail, dummy & & $\begin{array}{l}-0.058 \\
(0.24)\end{array}$ & $\begin{array}{l}-0.233 * * * \\
(4.06)\end{array}$ & & & & & $\begin{array}{l}0.169^{*} \\
(1.77)\end{array}$ & $\begin{array}{l}0.177^{*} \\
(1.88)\end{array}$ \\
\hline Blocking of shares, dummy & & $\begin{array}{l}0.307 \\
(1.11)\end{array}$ & & & & & & & \\
\hline Cumulative Voting, dummy & & $\begin{array}{l}0.518 * * \\
(1.96)\end{array}$ & $\begin{array}{l}0.339 * * * \\
(4.07)\end{array}$ & & & & & $\begin{array}{l}0.513 * * * \\
(2.85)\end{array}$ & $\begin{array}{l}0.580 * * * \\
(5.00)\end{array}$ \\
\hline Oppressed minority, dummy & & $\begin{array}{l}-0.219 \\
(1.00)\end{array}$ & $\begin{array}{l}-0.338 * * * \\
(3.29)\end{array}$ & & & & & $\begin{array}{l}-0.530^{* * * *} \\
(2.58)\end{array}$ & $\begin{array}{l}-0.600 \text { **** } \\
(4.63)\end{array}$ \\
\hline Preemptive Rights of new Issues & & $\begin{array}{l}0.386 \\
(1.40)\end{array}$ & $\begin{array}{l}0.146^{* * *} \\
(2.90)\end{array}$ & & & & & $\begin{array}{l}0.134 * \\
(1.70)\end{array}$ & $\begin{array}{l}0.128 * * \\
(2.48)\end{array}$ \\
\hline Votes to call ext. meeting & & $\begin{array}{r}-1.813 \\
(1.12)\end{array}$ & & & & & & & \\
\hline New antidirectors index & & $\begin{array}{l}-0.185 \\
(0.81)\end{array}$ & & & & & & & \\
\hline Mandatory Dividends, dummy & & $\begin{array}{r}-0.085 \\
(0.18)\end{array}$ & & & & & & & \\
\hline Rule of Law & & & & $\begin{array}{c}-0.085^{*} \\
(1.77)\end{array}$ & & & & & \\
\hline Bureaucratic Quality & & & & $\begin{array}{r}-0.002 \\
(0.06)\end{array}$ & & & & & \\
\hline Corruption & & & & $\begin{array}{c}-0.039^{*} \\
(1.87)\end{array}$ & $\begin{array}{l}-0.046 * * * \\
(3.24)\end{array}$ & & & $\begin{array}{l}-0.013 \\
(0.70)\end{array}$ & \\
\hline Risk of Repudiation & & & & $\begin{array}{l}-0.377 * * * * \\
(3.08)\end{array}$ & $\begin{array}{l}-0.325 * * * \\
(5.08)\end{array}$ & & & $\begin{array}{l}-0.115 \\
(1.10)\end{array}$ & $\begin{array}{l}-0.088^{* * * *} \\
(2.79)\end{array}$ \\
\hline Risk of Expropriation & & & & $\begin{array}{l}0.299 * * \\
(2.20)\end{array}$ & $\begin{array}{l}0.236 * * * \\
(3.58)\end{array}$ & & & $\begin{array}{l}0.028 \\
(0.29)\end{array}$ & \\
\hline Effective Judiciary & & & & $\begin{array}{l}0.114^{* *} \\
(2.44)\end{array}$ & $\begin{array}{l}0.098^{* * *} \\
(3.98)\end{array}$ & & & $\begin{array}{l}0.033 \\
(0.59)\end{array}$ & \\
\hline Accounting Standards & & & & & & $\begin{array}{c}-0.020 * * * \\
(3.36)\end{array}$ & $\begin{array}{c}-0.021 * * * \\
(3.79)\end{array}$ & $\begin{array}{c}-0.026 * * * \\
(2.99)\end{array}$ & $\begin{array}{c}-0.026 * * * \\
(3.73)\end{array}$ \\
\hline Corporate transparency & & & & & & $\begin{array}{c}-0.005^{* * * *} \\
(3.05)\end{array}$ & $\begin{array}{c}-0.005^{* * *} * \\
(3.01)\end{array}$ & $\begin{array}{c}-0.007 * * \\
(2.42)\end{array}$ & $\begin{array}{c}-0.007 * * * \\
(2.88)\end{array}$ \\
\hline Governance Disclosure & & & & & & $\begin{array}{l}0.007 * * \\
(2.52)\end{array}$ & $\begin{array}{l}0.007 * * \\
(2.49)\end{array}$ & $\begin{array}{l}0.015^{* *} \\
(2.34)\end{array}$ & $\begin{array}{l}0.017 * * * * \\
(4.28)\end{array}$ \\
\hline R\&D Disclosure & & & & & & $\begin{array}{l}0.004 * \\
(1.88)\end{array}$ & $\begin{array}{l}0.005^{* *} \\
(2.12)\end{array}$ & $\begin{array}{l}0.012 * * * \\
(3.28)\end{array}$ & $\begin{array}{l}0.013 * * * \\
(4.14)\end{array}$ \\
\hline Disclosure Requirements, Index & & & & & & $\begin{array}{l}0.494 * * * \\
(3.34)\end{array}$ & $\begin{array}{l}0.482 * * * \\
(3.29)\end{array}$ & $\begin{array}{l}0.191 \\
(0.67)\end{array}$ & \\
\hline Consolidation Disclosure & & & & & & $\begin{array}{l}-0.001 \\
(0.58)\end{array}$ & & & \\
\hline Number of observations & 337 & 310 & 322 & 271 & 322 & 337 & 337 & 322 & 322 \\
\hline Number of countries & 24 & 22 & 23 & 23 & 23 & 24 & 24 & 23 & 23 \\
\hline R2 (within) & 0.11 & 0.13 & 0.14 & 0.16 & 0.14 & 0.14 & 0.14 & 0.15 & 0.15 \\
\hline R2 (between) & 0.60 & 0.73 & 0.71 & 0.72 & 0.68 & 0.62 & 0.62 & 0.84 & 0.84 \\
\hline R2 (overall) & 0.25 & 0.37 & 0.36 & 0.41 & 0.35 & 0.33 & 0.33 & 0.42 & 0.42 \\
\hline
\end{tabular}

$*, * *, * * *$ denote significance at the $10 \%, 5 \%$, and $1 \%$ level, respectively. (Robust absolute) t-statistics in parentheses.

The results shown for each hypothesis present the coefficients and t-statistics for the first regressions estimated (including all explanatory variables) in the first column and the resulting final model for each hypothesis after the general-to-specific procedure laid out in section 3 in the respective second column. Column one presents the results for the base model. The remaining variables for each separate hypothesis are then included in the final model. The final column reports the results from general-to-specific based on this model. All regressions are estimated using random effects GLS. Tests for serial correlation in the error terms have been carried out as explained in section 3. Dummies for each year are included in all regressions but are omitted from the presentation in the table. All variables used are described in Appendix A. 
Base model

IMF program, dummy

Number of IPOs (log)

Economic growth

Return

Stock Market Turnover

\begin{tabular}{|cccccc|}
\hline$(1)$ & $(2)$ & $(3)$ & $(4)$ & $(5)$ & $(6)$ \\
Avg. Beta & Avg.Std.Err. & \% Sign. & $\mathrm{CDF}(0)$ & lower Bound & upper Bound \\
\hline
\end{tabular}

Full model

\begin{tabular}{|l|}
\hline Accounting Standards \\
R\&D Disclosure \\
Oppressed minority, dummy \\
Return \\
Governance Disclosure \\
Number of IPOs (log) \\
Civil law, dummy \\
Corporate transparency \\
IMF program, dummy \\
Risk of Repudiation \\
Cumulative Voting, dummy \\
Proxy Voting by Mail, dummy \\
Preemptive Rights of new Issues \\
Stock Market Turnover \\
Economic growth \\
\hline
\end{tabular}

\begin{tabular}{|cccccc|}
\hline-0.033 & 0.009 & 1.00 & 1.00 & -0.074 & 0.002 \\
0.015 & 0.004 & 0.99 & 1.00 & -0.006 & 0.032 \\
-0.650 & 0.187 & 0.93 & 0.99 & -1.956 & 0.478 \\
0.249 & 0.121 & 0.99 & 0.98 & -0.048 & 0.589 \\
0.015 & 0.005 & 0.80 & 0.98 & -0.008 & 0.045 \\
0.034 & 0.020 & 0.63 & 0.94 & -0.049 & 0.108 \\
-0.302 & 0.135 & 0.77 & 0.93 & -0.941 & 0.436 \\
-0.006 & 0.003 & 0.73 & 0.92 & -0.017 & 0.011 \\
0.214 & 0.148 & 0.26 & 0.90 & -0.205 & 0.928 \\
-0.104 & 0.062 & 0.49 & 0.88 & -0.459 & 0.310 \\
0.431 & 0.178 & 0.68 & 0.87 & -0.900 & 1.729 \\
0.129 & 0.109 & 0.64 & 0.80 & -0.553 & 0.524 \\
0.059 & 0.075 & 0.49 & 0.69 & -0.691 & 0.466 \\
1.220 & 3.037 & 0.08 & 0.59 & -9.569 & 18.073 \\
0.001 & 0.011 & 0.00 & 0.54 & -0.029 & 0.031 \\
\hline
\end{tabular}

Table 4 reports results for the Extreme Bounds Analysis estimated with random effects GLS. The results for the base (full) model are based on 1,793 (300) combinations with 315 (308) observations, on average. Dummies for each year are included in all regressions but not shown in the table. The upper part of the table presents the results for the base model while the lower part presents the results for the variables generated for the final model shown in table 3 (stemming from the general-to-specific procedure). Columns 1 and 2 present the average beta and standard error generated from all estimated combinations, respectively. Column 3 indicates the percentage of estimations in which a variable is significantly different from zero at the 5\% level and column 4 indicates the unweighted cumulative distribution function $(\mathrm{CDF}(0))$, i.e., the fraction of the cumulative distribution function lying on one side of zero. Columns 5 and 6 report the extreme bounds for the corresponding variable. Variables are sorted according to their $\operatorname{CDF}(0)$. 
Table 5: Extreme Bounds Analysis, additional variables, full model

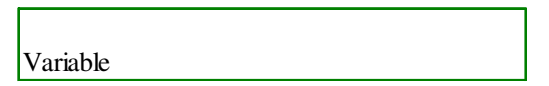

\begin{tabular}{|ccccccc|}
\hline$(1)$ & $(2)$ & $(3)$ & $(4)$ & $(5)$ & $(6)$ & $(7)$ \\
Avg. Beta & Avg.Std.Err. & $\%$ Sign. & $\mathrm{CDF}(0)$ & lower Bound & upper Bound & Avg. Obs. \\
\hline
\end{tabular}

Rule of Law

New antidirectors index

Blocking of shares, dummy

Consolidation Disclosure

Mandatory Dividends, dummy

Bureaucratic Quality

Effective Judiciary

Disclosure Requirements, Index

Corruption

One share-one vote, dummy

Risk of Expropriation

Votes to call ext. meeting

\begin{tabular}{|rllllll|}
\hline-0.088 & 0.040 & 0.87 & 0.97 & -0.227 & 0.031 & 271 \\
0.256 & 0.161 & 0.49 & 0.92 & -0.866 & 1.262 & 307 \\
0.304 & 0.219 & 0.47 & 0.89 & -0.862 & 1.246 & 307 \\
0.004 & 0.004 & 0.26 & 0.82 & -0.013 & 0.019 & 307 \\
-0.688 & 1.341 & 0.05 & 0.69 & -5.253 & 4.295 & 307 \\
-0.010 & 0.029 & 0.00 & 0.63 & -0.094 & 0.102 & 305 \\
0.033 & 0.109 & 0.02 & 0.63 & -0.335 & 0.362 & 307 \\
0.144 & 0.557 & 0.06 & 0.60 & -2.106 & 2.472 & 307 \\
-0.006 & 0.018 & 0.03 & 0.58 & -0.082 & 0.050 & 307 \\
-0.039 & 0.186 & 0.01 & 0.58 & -0.827 & 0.754 & 307 \\
-0.017 & 0.201 & 0.06 & 0.54 & -0.742 & 0.750 & 307 \\
0.156 & 1.163 & 0.06 & 0.51 & -6.008 & 8.760 & 299 \\
\hline
\end{tabular}

Table 5 reports results for the Extreme Bounds Analysis estimated with random effects GLS. Dummies for each year are included in all regressions but not shown in the table. Columns 1 and 2 present the average beta and standard error generated from all combinations estimated, respectively. Column 3 indicates the percentage of estimations in which the included variable is significantly different from zero at the 5\% level and column 4 indicates the unweighted cumulative distribution function $(\mathrm{CDF}(0))$, i.e., the fraction of the cumulative distribution function lying on one side of zero. Columns 5 and 6 report the extreme bounds for the corresponding variable, while the average number of observations included in the regressions is shown in column 7 . 
Hypothesis 1

\begin{tabular}{|c|c|c|}
\hline Variable & Description & Source \\
\hline $\begin{array}{l}\text { Civil vs. Common Law } \\
\text { Dummy }\end{array}$ & $\begin{array}{l}\text { Identifies the legal origin of the company } \\
\text { law or commercial code of each country. } \\
\text { The variable takes a value equal to } 1 \text { when } \\
\text { the country belongs to the civil law } \\
\text { tradition (i.e., all French, German and } \\
\text { Scandinavian codes), and } 0 \text { when the } \\
\text { country belongs to the Common law } \\
\text { tradition (i.e., English Common law). }\end{array}$ & La Porta et al. (1998) \\
\hline New anti-directors index & $\begin{array}{l}\text { This index of Anti-director rights is formed } \\
\text { by adding one when: (1) the country allows } \\
\text { shareholders to mail their proxy vote; (2) } \\
\text { shareholders are not required to deposit } \\
\text { their shares prior to the general } \\
\text { shareholders meeting; (3) cumulative } \\
\text { voting or proportional representation of } \\
\text { minorities on the board of directors is } \\
\text { allowed; (4) an oppressed minorities } \\
\text { mechanism is in place; (5) the minimum } \\
\text { percentage of share capital that entitles a } \\
\text { shareholder to call for an extraordinary } \\
\text { shareholders' meeting is less than or equal } \\
\text { to } 10 \% \text { (the sample median); or (6) when } \\
\text { shareholders have preemptive rights that } \\
\text { can only be waved by a shareholders } \\
\text { meeting. The range for the index is from } \\
\text { zero to six. }\end{array}$ & La Porta et al. (1998) \\
\hline $\begin{array}{l}\text { One-Share-One-Vote, } \\
\text { Dummy }\end{array}$ & $\begin{array}{l}\text { Equals one if the company law or } \\
\text { commercial code of the country requires } \\
\text { that ordinary shares carry one vote per } \\
\text { share, and zero otherwise. Equivalently, } \\
\text { this variable equals one when the law } \\
\text { prohibits the existence of both multiple- } \\
\text { voting and nonvoting ordinary shares and } \\
\text { does not allow firms to set a maximum } \\
\text { number of votes per shareholder } \\
\text { irrespective of the number of shares owned, } \\
\text { and zero otherwise. }\end{array}$ & La Porta et al. (1998) \\
\hline
\end{tabular}

Base Model

Base Model
\begin{tabular}{|l|l|l|}
\hline Variable & Description & Source \\
\hline Economic growth & Annual GDP Growth. & World Bank, WDI (2006) \\
\hline IMF program, dummy & $\begin{array}{l}\text { Indicates whether an IMF program has } \\
\text { been in effect for at least five months in a } \\
\text { given year. }\end{array}$ & Dreher (2006) \\
\hline Market Return & $\begin{array}{l}\text { Stock market return of the MSCI Index for } \\
\text { the corresponding country. }\end{array}$ & $\begin{array}{l}\text { MSCI Indices for developed and } \\
\text { emerging markets }\end{array}$ \\
\hline Stock Market Turnover & $\begin{array}{l}\text { Stock market total value traded to GDP. } \\
\text { Beck } \text { et al. (1999) }\end{array}$ \\
\hline LogIpo & $\begin{array}{l}\text { Annual Number of IPOs. Enters the } \\
\text { regression as the log. }\end{array}$ & $\begin{array}{l}\text { See Data Sources for the dependent } \\
\text { variable in Appendix C. }\end{array}$ \\
\hline
\end{tabular}

\section{Appendix A: Description and Sources of Variables}




\begin{tabular}{|c|c|c|}
\hline $\begin{array}{l}\text { Oppressed Minority, } \\
\text { Dummy }\end{array}$ & $\begin{array}{l}\text { Equals one if the company law or } \\
\text { commercial code grants minority } \\
\text { shareholders either a judicial venue to } \\
\text { challenge the decisions of management or } \\
\text { of the assembly or the right to step out of } \\
\text { the company by requiring the company to } \\
\text { purchase their shares when they object to } \\
\text { certain fundamental changes, such as } \\
\text { mergers, asset dispositions, and changes in } \\
\text { the articles of incorporation. The variable } \\
\text { equals zero otherwise. Minority } \\
\text { shareholders are defined as those } \\
\text { shareholders who own } 10 \% \text { of share capital } \\
\text { or less. }\end{array}$ & La Porta et al. (1998) \\
\hline $\begin{array}{l}\text { Blocking of Shares, } \\
\text { Dummy }\end{array}$ & $\begin{array}{l}\text { Equals one if the company law or } \\
\text { commercial code does not allow firms to } \\
\text { require that shareholders deposit their } \\
\text { shares prior to a general shareholders' } \\
\text { meeting, thus preventing them from selling } \\
\text { those shares for a number of days, and zero } \\
\text { otherwise. }\end{array}$ & La Porta et al. (1998) \\
\hline Mail Proxy & $\begin{array}{l}\text { Equals one if the company law or } \\
\text { commercial code allows shareholders to } \\
\text { mail their proxy vote to the firm, and zero } \\
\text { otherwise }\end{array}$ & La Porta et al. (1998) \\
\hline $\begin{array}{l}\text { Votes to Call extraordinary } \\
\text { Meeting }\end{array}$ & $\begin{array}{l}\text { The minimum percentage of ownership of } \\
\text { share capital that entitles a shareholder to } \\
\text { call for an extraordinary shareholders' } \\
\text { meeting; it ranges from } 1 \text { to } 33 \% \text {. }\end{array}$ & La Porta et al. (1998) \\
\hline Pre-emptive Rights & $\begin{array}{l}\text { Equals one when the Company Law or } \\
\text { Commercial Code grants shareholders the } \\
\text { first opportunity to buy new issues of stock } \\
\text { and this right can only be waived by a } \\
\text { shareholders' vote, and zero otherwise. }\end{array}$ & La Porta et al. (1998) \\
\hline Mandatory Dividends & $\begin{array}{l}\text { Equals the percentage of net income that } \\
\text { the Company Law or Commercial Code } \\
\text { requires firms to distribute as dividends } \\
\text { among ordinary stockholders. It takes a } \\
\text { value of zero for countries without such } \\
\text { restriction. }\end{array}$ & La Porta et al. (1998) \\
\hline Cumulative Voting & $\begin{array}{l}\text { Equals one if the Company Law or } \\
\text { Commercial Code allows shareholders to } \\
\text { cast all of their votes for one candidate } \\
\text { standing for election to the board of } \\
\text { directors (cumulative voting) or if the } \\
\text { Company Law or Commercial Code allows } \\
\text { a mechanism of proportional representation } \\
\text { in the board by which minority interests } \\
\text { may name a proportional number of } \\
\text { directors to the board, and zero otherwise. }\end{array}$ & La Porta et al. (1998) \\
\hline
\end{tabular}

Hypothesis 2

\begin{tabular}{|c|c|c|}
\hline Variable & Description & Source \\
\hline Rule of Law & $\begin{array}{l}\text { This variable "reflects the degree to which } \\
\text { the citizens of a country are willing to } \\
\text { accept the established institutions to make } \\
\text { and implement laws and adjudicate } \\
\text { disputes." Higher scores indicate: "sound } \\
\text { political institutions, a strong court system, } \\
\text { and provisions for an orderly succession of } \\
\text { power." Lower scores indicate: "a tradition }\end{array}$ & International Country Risk Guide \\
\hline
\end{tabular}




\begin{tabular}{|c|c|c|}
\hline & $\begin{array}{l}\text { of depending on physical force or illegal } \\
\text { means to settle claims." Upon changes in } \\
\text { government new leaders "may be less likely } \\
\text { to accept the obligations of the previous } \\
\text { regime." }\end{array}$ & \\
\hline Bureaucracy Quality & $\begin{array}{l}\text { High scores indicate "an established } \\
\text { mechanism for recruitment and training," } \\
\text { "autonomy from political pressure," and } \\
\text { "strength and expertise to govern without } \\
\text { drastic changes in policy or interruptions in } \\
\text { government services" when governments } \\
\text { change. }\end{array}$ & International Country Risk Guide \\
\hline Corruption & $\begin{array}{l}\text { Lower scores indicate "high government } \\
\text { officials are likely to demand special } \\
\text { payments" and that "illegal payments are } \\
\text { generally expected throughout lower levels } \\
\text { of government" in the form of "bribes } \\
\text { connected with import and export licenses, } \\
\text { exchange controls, tax assessment, police } \\
\text { protection, or loans." }\end{array}$ & International Country Risk Guide \\
\hline $\begin{array}{l}\text { Risk of Contract } \\
\text { Repudiation }\end{array}$ & $\begin{array}{l}\text { This indicator addresses the possibility that } \\
\text { foreign businesses, contractors, and } \\
\text { consultants face the risk of a modification } \\
\text { in a contract taking the form of a } \\
\text { repudiation, postponement, or scaling } \\
\text { down" due to "an income drop, budget } \\
\text { cutbacks, indigenization pressure, a change } \\
\text { in government, or a change in government } \\
\text { economic and social priorities." Lower } \\
\text { scores signify "a greater likelihood that a } \\
\text { country will modify or repudiate a contract } \\
\text { with a foreign business." }\end{array}$ & La Porta et al. (1998) \\
\hline Risk of Expropriation & $\begin{array}{l}\text { This variables evaluates the risk "outright } \\
\text { confiscation and forced nationalization" of } \\
\text { property. Lower ratings "are given to } \\
\text { countries where expropriation of private } \\
\text { foreign investment is a likely event." }\end{array}$ & La Porta et al. (1998) \\
\hline $\begin{array}{l}\text { Efficiency of the judicial } \\
\text { System }\end{array}$ & $\begin{array}{l}\text { Assessment of the "efficiency and integrity } \\
\text { of the legal environment as it affects } \\
\text { business, particularly foreign } \\
\text { firms"produced by the country-risk rating } \\
\text { agency Business International Corporation. } \\
\text { It "may be taken to represent investors' } \\
\text { assessments of conditions in the country in } \\
\text { question". Scale from } 0 \text { to } 10 \text {, with lower } \\
\text { scores lower efficiency levels. }\end{array}$ & La Porta et al. (1998) \\
\hline
\end{tabular}

\section{Hypothesis 3}

\begin{tabular}{|l|l|l|}
\hline Variable & Description & Source \\
\hline Corporate transparency & $\begin{array}{l}\text { Average ranking of the answers to the } \\
\text { following interim reporting questions: Ea } \\
\text { (frequency of reports), Ed-Ef (count of } \\
\text { disclosed items), and Eb (consolidation of } \\
\text { interim reports). }\end{array}$ & \\
\hline
\end{tabular}




\begin{tabular}{|c|c|c|}
\hline $\begin{array}{l}\text { R\&D Disclosure } \\
\text { Requirements }\end{array}$ & $\begin{array}{l}\text { Average ranking of the answers to the } \\
\text { following questions: A6g (R\&D), B3f } \\
\text { (capital expenditure), Ca (subsidiaries), Cb } \\
\text { (segment-product), Cc (segment- } \\
\text { geographic), and D1 (accounting policy). }\end{array}$ & Bushman et al. (2004). \\
\hline Consolidation & $\begin{array}{l}\text { Average ranking of the answers to the } \\
\text { following questions: A3 (consolidation) } \\
\text { and A6p (discretionary reserves). See } \\
\text { Bushman, Robert M., Joseph D. Piotroski, } \\
\text { and Abbie J. Smith, 2004, "What } \\
\text { Determines Corporate Transparency?", } \\
\text { Journal of Accounting Research. }\end{array}$ & Bushman et al. (2004). \\
\hline Accounting & $\begin{array}{l}\text { Index created by examining and rating } \\
\text { companies' } 1995 \text { annual reports on their } \\
\text { inclusion or omission of } 90 \text { items. These } \\
\text { items fall into seven categories: general } \\
\text { information, income statements, balance } \\
\text { sheets, funds flow statement, accounting } \\
\text { standards, stock data, and special items. A } \\
\text { minimum of } 3 \text { companies in each country } \\
\text { were studied. }\end{array}$ & Bushman et al. (2004) \\
\hline Governance & $\begin{array}{l}\text { Average ranking of the answers to the } \\
\text { following questions: B2a (range of } \\
\text { shareholdings), B2b (major shareholders), } \\
\text { Ce (management information), Cf (list of } \\
\text { board members and their affiliations), Cg } \\
\text { (remuneration of directors and officers), } \\
\text { and Ch (shares owned by directors and } \\
\text { employees). }\end{array}$ & Bushman et al. (2004) \\
\hline $\begin{array}{l}\text { Disclosure requirements, } \\
\text { index }\end{array}$ & $\begin{array}{l}\text { Index of disclosure requirements with } \\
\text { respect to the Prospect; Compensation; } \\
\text { Shareholders; Inside ownership; Contracts } \\
\text { Irregular; and Transactions. }\end{array}$ & La Porta et al. (2006) \\
\hline
\end{tabular}




\section{Appendix B: Extreme Bounds Analysis (EBA)}

To examine both the sensitivity of our baseline model and the coefficients of our explanatory variables of interest to changes in the model specification we apply (variants) of the so-called Extreme Bounds Analysis (EBA) as suggested by Leamer (1983) and Levine and Renelt (1992). EBA has been widely used in the economic growth literature. ${ }^{14}$ The central difficulty in this research - which also applies to the research topic of the present paper - is that several different models may all seem reasonable given the data, but yield different conclusions about the parameters of interest. The EBA can be exemplified as follows. Equations of the following general form are estimated:

$$
Y=\alpha M+\beta F+\gamma Z+u
$$

where $Y$ is the dependent variable; $M$ is a vector of 'standard' explanatory variables; $F$ is the variable of interest; $Z$ is a vector of up to three possible additional explanatory variables, which according to the literature may be related to the dependent variable; and $u$ is an error term. The extreme bounds test for variable $F$ states that if the lower extreme bound for $\beta-$ i.e., the lowest value for $\beta$ minus two standard deviations - is negative, while the upper extreme bound for $\beta$ - i.e., the highest value for $\beta$ plus two standard deviations - is positive, the variable $F$ is not robustly related to $Y$.

As argued by Temple (2000), it is rare in empirical research that we can say with certainty that one model dominates all other possibilities in all dimensions. In these circumstances, it makes sense to provide information about how sensitive the findings are to alternative modelling choices. The EBA provides a relatively simple means of doing exactly this. Still, the EBA has been criticized in the literature. Sala-i-Martin (1997) argues that the test applied in the Extreme Bounds Analysis poses too rigid a threshold in most cases. If the distribution of $\beta$ has some positive and some negative support, then one is bound to find at least one regression for which the estimated coefficient changes sign if enough regressions are run. We will therefore not only report the extreme bounds, but also the percentage of the regressions in which the coefficient of the variable $F$ is significantly different from zero at the $5 \%$ level. Moreover, instead of analyzing just the extreme bounds of the estimates of the coefficient of a particular variable, we follow Sala-i-Martin's (1997) suggestion to analyze the entire distribution. Following this suggestion, we not only report the unweighted parameter estimate of $\beta$ and its standard deviation but also the unweighted cumulative distribution function $(\mathrm{CDF}(0))$, i.e., the fraction of the cumulative distribution function lying on one side of zero. We will base our conclusions on the Sala-i-Martin variant of the EBA.

\footnotetext{
${ }^{14}$ See, e.g., Levine and Renelt (1992), Sala-i-Martin (1997).
} 


\section{Appendix C: Data Sources}

\section{Australia:}

Data for 1992 -2005 is from: Alavi, A., Pham, K.P., Pham, T.M. (2008), Pre-IPO ownership structure and its impact on the IPO process, Journal of Banking and Finance, 32, 2361 - 2375. The same data has been provided by Li-Anne Woo, Bond University, Australia.

Austria:

Data for 1988 -2005 is from: Aussenegg W. (1997) Die Performance Österreichischer Initial Public Offerings, in: Finanzmarkt and Portfolio Management, 11, 413-431. and Aussenegg W. (2006) Underpricing and the Aftermarket Performance of Initial Public Offerings - The Case of Austria, in: Greg N. Gregoriou (Ed.), Initial Public Offerings: An International Perspective, S. 187-213, Elsevier, Quantitative Finance Series, Amsterdam, 2006, ISBN-13: 978-0-7506-7975-6, ISBN-10: 0-7506-7975-1.

Canada:

Data for 1991 -2005 has been provided by Jean-Marc Suret and Cecile Carpentier, Laval University, Quebec.

Denmark:

Data for the period 1988-1992 is from Jakobson, J. and J. Sorenson (2002): Decomposing and Testing Long-run Returns with an application to initial public offerings in Denmark, Working Paper, Copenhagen Business School.

Data for the period 1993 to 2005 has been provided by IPOX Schuster.

Finland:

Data for Finland from 1988 - 2005 has been provided by Matti Keloharju, Helsinki School of Economics

France:

French data from 1988-1991 and from 1999-2005 has been provided by IPOX Schuster.

Data for the period 1992 to 1998 is from Derrien, F. and K. Womack (2003) Auctions vs. Bookbuilding and the Control of Underpricing in Hot IPO Markets, Review of Financial Studies, 16, 31-61

Germany:

German IPO data for 1988 - 2005 has been provided by Jay Ritter, University of Florida

Greece:

Data for 1988 -2005 is from: IPO Underpricing Data for Greece is from Christos Nounis (2005) The Greek IPO Initial Returns And The Price Cap Constraints: Evidence from the Athens Stock Exchange, Working Paper, National and Kapodistrian University of Athens.

Hong-Kong, China:

Underpricing for the period 1990-1992 and 2004/2005 has been provided by IPOX Schuster. Data for the period 1993-2005 is from Suresh Radhakrishnan, University of Texas, Dallas.

India: 
Indian IPO data for 1990 - 2005 is from Marisetty, V. and M. Subrahmanyam (2008): Group Affiliations and the performance of Initial Public Offerenings in the Indian Stock market, Working Paper, Stern School of Business, New York.

Italy:

Italian data for 1988 - 2005 has been provided by Silvio Masmara, University of Bergamo.

Japan:

Japanese data for the period 1990 to 1996 is from Ritter, J., Packer, F. and Hamao, Y. (2000) Institutional Affiliation and the Role of Venture Capital: Evidence from Initial Public Offerings in Japan, Pacific-Basin Finance Journal, 8, 529-558.

Data for the period 1996-2000 is from Kaneko, T. and R. Pettway (2003) Auctions versus Book-Building Underwriting of Japanese IPOs: OTC, Mothers, and NASDAQ-Japan Issues, Pacific-Basin Finance Journal, 11, 439-462

Data for the period 2002- 2005 has been provided by IPOX Schuster.

Malaysia:

Malaysian data for the period 1990-2000 is from Ahmad-Zaluki,N.A., Campbell, K., and Goodacre, A. (2007) The Long Run Share Price Performance of Malaysian Initial Public Offerings (IPOs), Journal of Business Finance \& Accounting, 34, 78-110.

Data for the period 2001 - 2005 has been provided by IPOX Schuster

The Netherlands:

Data for the Netherlands for the period 1990 - 1999 has been provided by Tjalling van der Goot, University of Amsterdam

Data for the period 2000 - 2005 has been provided by IPOX Schuster.

New Zealand:

Data for New Zealand for 1988 - 2005 has been provided by IPOX Schuster

Norway.

Data for the period 1990 to 1995 for Norway is from Saettem, F. Emilsen, H. and Pedersen, K. Børsintroduksjoner, BETA - Tidsskrift for bedrifts økonomi, Årg. 11, nr. 1, 1997, ss. 1-13. Data for the period 1996 - 2005 has been provided by IPOX Schuster

Philippines:

Data for the period 1990 to 1996 is from Sullivan, M. and Unite, A. (2001) The influence of group affiliation and the underwriting process on emerging market IPOs: The case of the Philippines, Pacific-Basin Finance Journal, 9, 487-512

Data for the period 1997 to 2005 has been provided by IPOX Schuster

Singapore:

Data for Singapore for 1988 - 2005 has been provided by IPOX Schuster

Spain: 
Spanish data for 1988 - 2003 is from Alvarez, S and Fernandez A, I., 2003. La Explicacion de la Infravaloracion de las salidas a bolsa, Revista de Economia Aplicada, Vol. XI, No. 33: 4964.

Data for 2004/2005 has been provided by Susana Alvarez Otero, Universidad de Oviedo. The same numbers have also been provided by Carmen Ansotegui and Jordi Fabregat, Esade Business School

Sweden:

Swedish numbers for 1988 - 2005 have been provided by IPOX Schuster

Switzerland:

IPO Underpricing Data for Switzerland for 1988 - 2005 is from Drobetz, W., M. Kammermann, and U. Wälchli (2005) Long-Run Performance of Initial Public Offerings: The Evidence for Switzerland, Schmalenbach Business Review, 59, 253-275.

United Kingdom:

Data for the UK for 1988 - 2005 has been provided by IPOX Schuster

United States:

US data for 1988 - 2005 has been provided by Jay Ritter, University of Florida: http://bear.cba.ufl.edu/ritter/ipodata.htm.

About IPOX Schuster:

IPOX Schuster LLC is an independent, research-driven financial services firm specializing in financial products design related to global IPOs. The underlying philosophy involves classifying IPOs as a separate equity sector for a substantial period of time in aftermarket trading. The main product is the series of IPOX(r) IPO Indexes, a set of 17 indexes encompassing an index technology which allows for scaleable, investable and sustainable exposure into global IPO performance. The company has its roots in academic work on IPOs pursued in the Financial Markets Group (FMG) at the London School of Economics (LSE). IPOX Schuster LLC was officially incorporated in 2004. 